\title{
The effectiveness of intramedullary nailing in humeral diaphysis fractures and non-unions
}

\author{
Humerus cisim kırık ve kaynamamalarında intramedüller çivilemenin etkinliği
}

\author{
Alp Akman
}

Pamukkale Üniversitesi, Tıp Fakültesi, Ortopedi ve Travmatoloji ABD, Denizli

\begin{abstract}
Purpose:The analysis of treatment results of humeral non-unions with intramedullary nailing (IMN) according to primary treatment is not argued convincingly in literature.

Materials and methods: The results of 39 patients who treated with intramedullary nailing for humerus diaphysis fracture or non-union analysed in this study. An antegrade IMN technique was used with an interlocking intramedullary nail (Russell-Taylor type) in all cases. Twenty-six of these patients had primary IMN, seven had revision for failed plating and six had exchange IMN.

Results:The non-union rate was $15 \%$ in primary IMN, $29 \%$ in the revision for failed plating and $83 \%$ in exchange IMN groups. The average time to union were found as 14 weeks in the primary IMN and 20 weeks in the revision for failed plating. Even though revision for failed plating had similar healing rate with primary IMN $(p>0.05)$, the healing time significantly increased. $(p<0.05)$ The exchange IMN had the worst results. $(p<0.05$ against other groups).

Conclusion: IMN for humeral shaft fracture may be considered as an effective method of primary treatment. Exchange IMN in the humerus seemed to be a non-effective treatment modality and should be better to be avoided. In contrast IMN for a non-union after failed plating is an effective treatment. The non-unions of humerus shaft should be better to be treated with changing the implant type.
\end{abstract}

Pam Med J 2017;(1):33-38

Key words: Humeral diaphysis fractures, intramedullary nailing, complications, non-union.

Özet

Amaç:Intramedüller çivi sonrasında gelişen humerus kaynamamaları üzerine yapılmış daha önceki çalışmalar, ilk tedavi yöntemine göre sonuçların karşılaştıııımasını yeterince tartışmamaktadır.

Gereç ve yöntem: Bu çalışmada humerus cisim kırı̆ı tanısı ya da kaynamaması nedeniyle IMN uygulanmış 39 hastanın sonuçları retrospektif olarak analiz edilmiştir. Çalışma hastalarının tamamında (Russell-Taylor tipi) antegrat intramedüller çivi kullanılmıştır. Bu hastaların 26 'sı primer vaka olup, yedisinde öncesinde başarısız plaklama mevcuttu. Altı vakaya çivi değiştirme uygulanmıştı.

Bulgular: Primer çivilemede $\% 15$, başarısız plaklama revizyonunda $\% 29$ ve çivi değiştirmede ise $\% 83$ oranında kaynamama mevcuttu. Ortalama kaynama süresi primer çivilemede 14 hafta, başarısız plaklama revizyonunda ise 20 hafta idi. Başarısız plaklama revizyonu, primer çivileme ile benzer kaynama oranlarına sahip olmakla beraber $(p>0.05)$, kaynama süresi anlamlı şekilde artmıştı $(p<0.05)$. Çivi değiştirme en kötü sonuçlara sahipti (diğer gruplara karşı $p<0.05$ ).

Sonuç: Humerus şaft kııı̆ı için intramedüller çivileme etkin bir primer tedavi yöntemi olarak kabul edilebilir. Çivi değiştirme tekniği başarısız bir tedavi yöntemi olarak görünmekte olup, uygulamadan kaçınılmalıdır. Buna karşın başarısız plaklama sonrasında intramedüller çivi ile revizyon etkili bir yöntemdir.

Pam Tıp Derg 2017;(1):33-38

Anahtar sözcükler: Humerus cisim kırıkları, intramedüller çivileme, komplikasyonlar, kaynamama.

\footnotetext{
Alp Akman

Yazışma Adresi: Pamukkale Üniversitesi, Tıp Fakültesi, Ortopedi ve Travmatoloji ABD, Denizli. e-mail: alpakman@gmail.com
} 


\section{Introduction}

A fracture of the humeral shaft incidence is approximately $1-5 \%$ in all fractures $[1,2]$. Humeral fractures are generally treated nonoperatively and successful healing occurs in $90 \%$ of cases [3]. Surgical stabilization is especially considered to be the best treatment for bilateral fractures of the humerus and ipsilateral fractures of the humerus and forearm, as well as in cases of polytrauma, vascular injury and failed conservative treatment $[4,5]$. Use of a dynamic compression plate usually gives satisfactory results [4]. However, it requires extensive dissection and is complicated by the proximity of the radial nerve and the risk of mechanical failure in osteoporotic bone. Intramedullary nailing (IMN) requires less invasive surgery and reaming can yield autograft material. IMN also gives good results with very few complications for index surgery [6].

Several operative treatment options for the management of humeral non-union have been described including plates, external fixators and IMN [7]. Humeral non-union following IMN has its own problems [7]. The previous studies on the treatment of humeral non-unions with IMN failed to emphasize treatment results according to index surgery [8].

In this study, six years' experience of IMN is presented in a retrospective analysis. Index surgery results are compared with the results of non-union cases. Furthermore, non-union cases were analyzed according to index surgery which is not argued convincingly in literature. So we focused on this point in this study.

\section{Materials and methods}

Patients that were operated in a single hospital between August 2009 and August 2014 with humeral IMN were included in this retrospective study. This study was approved by the local ethical committee. An informed consent was obtained from all the patients. The inclusion criteria of the study were; (1) humeral shaft fractures (within $4 \mathrm{~cm}$ of proximal and distal end of humerus) which required operative intervention and were treated with IMN, and (2) patients of aged 18 and above. The exclusion criteria of study were; (1) pathological fractures, (2) infected fractures, (3) segmental fractures, (4) index surgeries other than plating or IMN and (5) patients without a regular follow-up.
After applying the exclusion criteria, thirtynine patients with interlocking IMN were included in the study for the final analysis. Twenty-six of these patients had primary IMN, seven had revision with IMN for failed plating and six had exchange IMN. The surgical indications for primary humeral fractures were failed to achieve acceptable reduction with closed methods, patients that are not compliant to conservative treatment and patients with multiple injuries.-

An antegrade technique was used with an interlocking intramedullary nail (RussellTaylor type) in all cases. In all revision cases, autologous bone graft was used. In the primary IMN, no graft was used. Additional stabilization (plaster, brace or splint) was not applied to any of the patients. The patients included in this study were followed up every 6 weeks, 12 weeks, 6 months, 9 months, 12 months and annually after injury with antero-posterior and lateral radiograms were taken in each control.

Demographics and injury characteristics including age, gender, side, dominant side, cause of fracture with its energy level, fracture type (according to AO classification [9]), Gustilo-Andersen type [10] and the presence of associated fracture were recorded. Falls above one and half meter height, motor vehicle accidents were accepted as high energy trauma.

Fracture location, morphology and comminution were recorded. Bone union was determined by radiographic evidence of cortical bone bridging in three of four cortices at the fracture site, stable implant position on radiographs. A radiographic non-union was defined as there was no evidence of union by four months after injury whereas bone union between four to eight months was accepted as a delayed union. Non-union, time to union and complications were noted for all cases. The complications were prominence of nail from nail, countersinking of nail during follow-up, fracture distraction were determined from post-operative radiograms.

Modified classification of Stewart and Hundley [11] was used to evaluate the results at follow-up.

SPSS version 18 (IBM Corp., New York, USA) was used for statistical analysis. Chisquare was used for categorical factors and outcomes. Mann-Whitney $U$ test was used for evaluation of two-factor groups and Kruskal- 
Wallis test for more than two factor groups. The data analyzed within $95 \%$ confidence interval and $p$ values less than 0.05 were considered as statistically significant.

\section{Results}

Twenty-three (64\%) of thirty-six patients were male and sixteen (\%36) were female. The average age was 47 (18-87). There were twenty-one (58\%) right and eighteen (42\%) left humerus fractures. Right hand was dominant in all patients except for one. Twenty-three $(64 \%)$ of the patients had high and sixteen of them (36\%) had low energy injuries. Only one fracture had a history of open fracture due to gunshot wound and internal fixation was applied with plate ten years ago. Six patients $(17 \%)$ had $12-\mathrm{A} 1$, ten patients $(28 \%)$ had $12-\mathrm{A} 2$, nine patients $(25 \%)$ had $12-A 3$, four patients $(11 \%)$ had $12-\mathrm{B} 1$, two patients (5\%) had $12-\mathrm{B} 2$ and eight patients (22\%) had 12-C1 type fractures according to $\mathrm{AO}$ classification. There were no 12-B3, 12-C2 or 12-C3 type fractures. While twenty-seven of the patients $(75 \%)$ had isolated humerus fractures, twelve $(25 \%)$ had multiple fractures. Average follow-up period was 22.8 months (12-65) (Table 1).

Table 1. The age, follow-up time and time to union among the study groups.

\begin{tabular}{lllll}
\hline & All & Primary nailing & Revision for failed plating & Exchange nailing \\
\hline Age & $47.3 \pm 20.8$ & $47.0 \pm 20.9$ & $43.1 \pm 18.8$ & $53.2 \pm 25.1$ \\
(years) & $(18-87)$ & $(18-87)$ & $(22-66)$ & $(18-77)$ \\
Follow-up time (months) & $22.8 \pm 13.0$ & $18.8 \pm 7.4$ & $28.3 \pm 17.1$ & $33.6 \pm 19.8$ \\
& $(12-65)$ & $(12-33)$ & $(13-54)$ & $(15-65)$ \\
Time to union (weeks) & $15.3 \pm 7.0$ & $13.7 \pm 6.5$ & $19.8 \pm 5.2$ & 28 \\
& $(5-28)$ & $(5-28)$ & $(13-27)$ & \\
\hline
\end{tabular}

All values are given in the form of mean \pm standard deviation; range (minimum - maximum).

The primary IMN group was composed of eighteen patients $(69 \%)$ with failure to achieve acceptable reduction by closed methods, four patients $(15 \%)$ were not compliant to conservative treatment and four patients (15\%) with multiple injuries. The non-union rate was $15.4 \%$ in primary IMN, $28.5 \%$ in the revision for failed plating and $83.3 \%$ in exchange IMN groups (Table 2). The average time to union was found as 13.7 weeks in the primary IMN and 19.8 weeks in the revision for failed plating (Table 1). Even though revision for failed plating had similar healing rate with primary IMN $(p>0.05)$, the healing time significantly increased $(p<0.05)$. The exchange IMN had the worst results. $(p<0.05$ against primary IMN and $p<0.05$ against revision for failed plating) (Figure 1). There was just one delayed union (at 28 weeks) in exchange IMN.

Among the technical complications, the prominence of nail from humeral head was seen in three cases $(7.7 \%)$ and caused painful shoulder joint and limited the motion in all. Two patients in the revision IMN group ended with non-union whereas one patient in the primary IMN group ended with delayed union. In one case in the primary IMN group (2.6\%) countersinking of nail was noticed after one month of follow-up and delayed bone union was achieved. Distraction of the fracture line (>5 mm) was seen in three cases $(7.7 \%)$. One patient affected in the revision IMN group ended with non-union whereas two affected patients in the primary IMN group ended with union. (Table 2). There was single radial nerve palsy after IMN application. Thus, risk was $2.6 \%$ for a new palsy. The-patient had recovered in the fourth month without any sequel.

Modified Stewart and Hundley scoring ended up with $23.1 \%$ poor results in primary IMN, $42.9 \%$ in revision for failed plating and $83.3 \%$ in exchange IMN (Table 1).

\section{Discussion}

The most important finding of this study is that there is a significant effect of the type of implant used in the index surgery on revision cases. There was a significantly better healing after failed plating rather than nailing. In fact, the healing rate in the non-unions after plating treated with nailing was on par with primary nailing. These results for low performance of exchange nailing can be attributed to its unique problems. First, damage to the endosteal blood supply caused by [12-14]. Also, the humeral non-unions experience rotational and distraction 
(gravity) forces, as opposed to the compressive force of weight-bearing in lower-extremity nonunions [15]. The reduced axial loading by IMN is considered a further disadvantage [12]. Exchange IMN for a non-union has high failure rates [6, 15]. Previous IMN possibly causes enlarging of the nail, poor endosteal circulation secondary to repeated reaming [6], injury of previous surgeries, or osteopenia either primary or secondary to immobilization [13, 16]. The cortical thinning due to the so-called "windshield wiper" effect and bone loss at the non-union site make reaming difficult and may lead to instability of a newly inserted exchange nail [15]. Initial fracture management by means other than IMN may not cause as much cortical erosion and bone loss at the non-union site as a failed nail [15]. These findings are supported by this study's results as very high union rates were achieved after failed plating which was very low after exchange IMN. For the overall results, non-union was the main factor for poor outcome.

The non-operative treatment of humeral shaft fractures has been traditionally regarded as the 'gold standard', but more and more of these fractures are being treated operatively [17, 18]. Although IMN is a well-established method in the treatment of tibial and femoral diaphysis fractures, its use in the treatment of humeral shaft fractures is still controversial. From a biomechanical standpoint, the intramedullary positioning of these devices places them in line with the mechanical axis of the humeral diaphysis, thereby subjecting the implant to lower bending loads. Thus, the nail has "loadsharing" capacity and mitigates the potential effects that stress shielding when compared with plating $[19,20]$. IMN is a minimal invasive procedure and the risk of nerve damage is also low [16, 21]. However, IMN provides less rotational control and axial stability due to the anatomy of the medullary canal and the lack of axial compression force as humerus is a non-weight bearing bone [22]. Several recent prospective randomized studies have shown that although specific complications may differ, both union rates and functional results are comparable between IMN and plating [23, 24]. The non-union rate reported in published studies was between $0 \%$ to $24 \%$ (average $6 \%$ ) and the mean delay to healing was around 13 weeks for locked IM nails [25]. This study's results had similar time to union compared to previous studies, but the non-union rate is on the high side. Our institution is a tertiary reference center in the region. Because of this, the most of cases admitted are cases with complicated courses even with primary fractures. This may be the reason for higher percentage of non-unions.

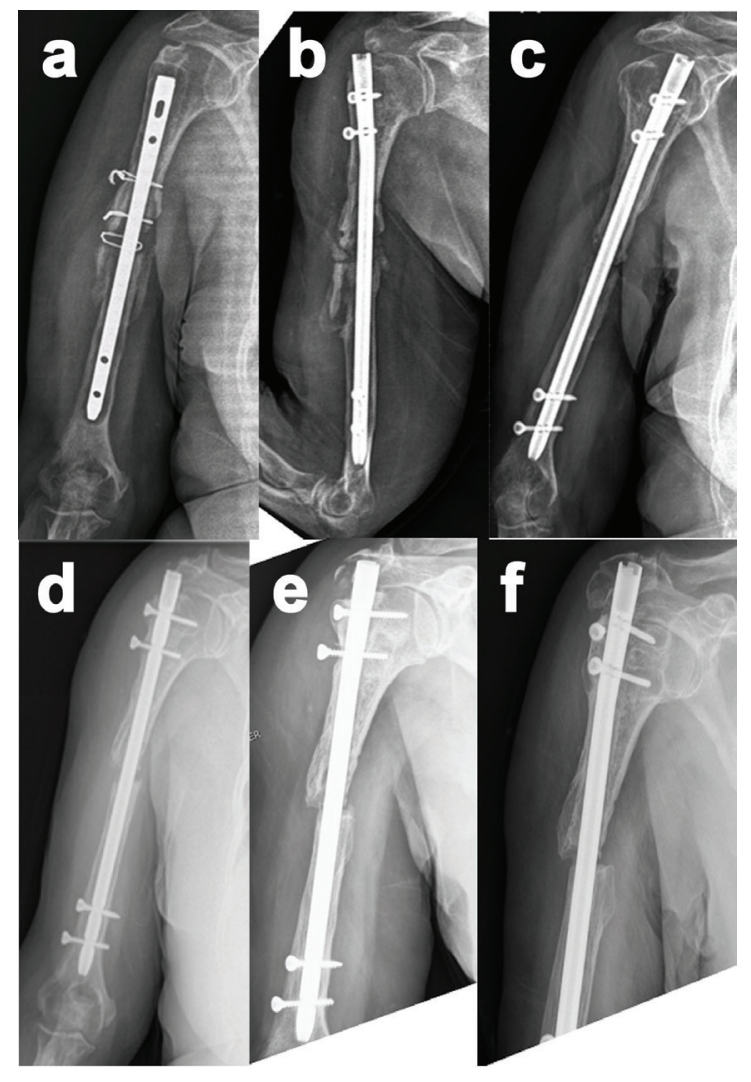

Figure 1. A case of failed exchange IMN: (A) 72 years of age woman sustained right humeral fracture due to fall onto ground. (B) Second operation by exchange antegrade locked IMN. At second month of follow-up, there was prominence of nail from nail from humeral head. (C) At her fifth month of follow-up with no signs of healing. (D) At her first year of follow-up; countersinking of nail was increased with the loosening of the second proximal locking screw. (E) At her third year of follow-up; the acromion was severely eroded now. $(F)$ At her fifth year of follow-up; the most proximal locking screw was broken.

Other problems associated with use of IMN in the humerus include; impairment of shoulder function, which could be because of impingement due to proximal migration of nail, rotator cuff violation, and adhesive capsulitis [23]. Restriction of shoulder movements and risk of delayed union have been suggested 
Table 2. Comparative evaluation of functional results and complications among groups.

\begin{tabular}{|c|c|c|c|c|c|}
\hline & & Total (n:39) & $\begin{array}{l}\text { Primary } \\
\text { nailing } \\
(\mathrm{n}: 26)\end{array}$ & $\begin{array}{l}\text { Revision for } \\
\text { failed plating } \\
(\mathrm{n}: 7)\end{array}$ & $\begin{array}{l}\text { Exchange } \\
\text { nailing }(\mathrm{n}: 6)\end{array}$ \\
\hline \multirow{3}{*}{ Study group } & Union & $17(43.6 \%)$ & $16(61.5 \%)$ & $\begin{array}{l}1 \\
(14.3 \%)\end{array}$ & $\begin{array}{l}0 \\
(0.0 \%)\end{array}$ \\
\hline & Delayed union & $11(28.2 \%)$ & $\begin{array}{l}6 \\
(23.1 \%)\end{array}$ & $\begin{array}{l}4 \\
(57.1 \%)\end{array}$ & $\begin{array}{l}1 \\
(16.7 \%)\end{array}$ \\
\hline & Non-union & $11(36.4 \%)$ & $\begin{array}{l}4 \\
(15.4 \%)\end{array}$ & $\begin{array}{l}2 \\
(28.6 \%)\end{array}$ & $\begin{array}{l}5 \\
(83.3 \%)\end{array}$ \\
\hline \multirow{4}{*}{$\begin{array}{l}\text { Modified Stewart and } \\
\text { Hundley score }\end{array}$} & Very good & $\begin{array}{l}17 \\
(43.5 \%)\end{array}$ & $14(53.8 \%)$ & $\begin{array}{l}3 \\
(42.9 \%)\end{array}$ & $\begin{array}{l}0 \\
(0.0 \%)\end{array}$ \\
\hline & Good & $\begin{array}{l}3 \\
(7.7 \%)\end{array}$ & $\begin{array}{l}2 \\
(7.7 \%)\end{array}$ & $\begin{array}{l}0 \\
(0.0 \%)\end{array}$ & $\begin{array}{l}1 \\
(16.7 \%)\end{array}$ \\
\hline & Satisfactory & $\begin{array}{l}4 \\
(10.3 \%)\end{array}$ & $4(15.4 \%)$ & $\begin{array}{l}1 \\
(14.3 \%)\end{array}$ & $\begin{array}{l}0 \\
(0.0 \%)\end{array}$ \\
\hline & Poor & $15(38.5 \%)$ & $\begin{array}{l}6 \\
(23.1 \%) \\
\end{array}$ & $\begin{array}{l}3 \\
(42.9 \%) \\
\end{array}$ & $\begin{array}{l}5 \\
(83.3 \%) \\
\end{array}$ \\
\hline \multirow{5}{*}{$\begin{array}{l}\text { Technical } \\
\text { complications }\end{array}$} & $\begin{array}{l}\text { Prominence of nail on } \\
\text { humeral head }\end{array}$ & $\begin{array}{l}3 \\
(7.7 \%)\end{array}$ & $\begin{array}{l}1 \\
(3.8 \%)\end{array}$ & $\begin{array}{l}0 \\
(0.0 \%)\end{array}$ & $\begin{array}{l}2 \\
(33.3 \%)\end{array}$ \\
\hline & Countersinking of nail & $\begin{array}{l}1 \\
(2.6 \%)\end{array}$ & $\begin{array}{l}1 \\
(3.8 \%)\end{array}$ & $\begin{array}{l}0 \\
(0.0 \%)\end{array}$ & $\begin{array}{l}0 \\
(0.0 \%)\end{array}$ \\
\hline & $\begin{array}{l}\text { Distraction of fracture } \\
(>5 \mathrm{~mm})\end{array}$ & $\begin{array}{l}3 \\
(7.7 \%)\end{array}$ & $\begin{array}{l}2 \\
(7.7 \%)\end{array}$ & $\begin{array}{l}0 \\
(0.0 \%)\end{array}$ & $\begin{array}{l}1 \\
(17.6 \%)\end{array}$ \\
\hline & $\begin{array}{l}\text { Extra diaphyseal } \\
\text { fracture }\end{array}$ & $\begin{array}{l}1 \\
(2.6 \%)\end{array}$ & $\begin{array}{l}1 \\
(3.8 \%)\end{array}$ & $\begin{array}{l}0 \\
(0.0 \%)\end{array}$ & $\begin{array}{l}0 \\
(0.0 \%)\end{array}$ \\
\hline & None & $31(79.5 \%)$ & $21(80.8 \%)$ & $\begin{array}{l}7 \\
(100.0 \%)\end{array}$ & $\begin{array}{l}3 \\
(50.0 \%)\end{array}$ \\
\hline
\end{tabular}

All values are given in the form of number (ratio in group ;\%).

as concerns with antegrade $\operatorname{IMN}[23,24]$. The most common technical complication in this series $(7.7 \%)$ was the prominence of nail from humeral head that resulted in painful and restricted shoulder movements with patient discomfort. Robinson et al. [5] pointed out that the advantages of antegrade IMN are largely overrun by the limitation of shoulder function. Distraction of the fracture (over $5 \mathrm{~mm}$ ) is observed in three cases which resulted in non-union in one exchange IMN case $(17 \%)$ and union in two $(8 \%)$ primary IMN cases. The prominence of nail from humeral head should be avoided. Selecting a shorter nail than the pre-determinated length of nail prevented such conditions in many cases.

The limitations of this study include the small sample size and the retrospective study design, with inherent operation technique, implant variability and lack of treatment protocols as well as difficulty in complete data retrieval. There was a lack of standardization as to when radiographs are obtained in follow up for this injury. This lack of standardization as to time intervals in between when radiographs were taken makes it difficult to determine exactly when healing took place. The implants that were used not a single type as among available systems were available concurrently which changed time to time.

In conclusion, IMN for humeral shaft fracture may be considered as an effective method of primary treatment. Exchange IMN in the humerus seemed to be a non-effective treatment modality and should be avoided. In contrast, IMN for a non-union after failed plating seemed to be an effective treatment. The nonunions of humerus shaft should be treated with changing the implant type. The prominence of nail from humeral head caused painful and limited shoulder movements in all affected cases. Further research needs to be done about treatment strategy especially exchanging the implant type in humerus shaft non-unions. 


\section{Acknowledgments}

None.

\section{Disclosure and Conflict of Interest}

The article is not published or presented elsewhere. The author did not receive and will not receive any benefits or funding from any commercial party related directly or indirectly to the subject of this article. The author declares that he had no conflict of interest.

\section{References}

1. Ekholm R, Adami J, Tidermark J, Hansson K, Tornkvist $\mathrm{H}$, Ponzer S. Fractures of the shaft of the humerus. An epidemiological study of 401 fractures. J Bone Joint Surg Br 2006;88:1469-1473.

2. Court-Brown CM, Caesar B. Epidemiology of adult fractures: A review. Injury 2006;37:691-697.

3. Sarmiento A, Waddell JP, Latta LL. Diaphyseal humeral fractures: treatment options. Instr Course Lect 2002;51:257-269.

4. Bell MJ, Beauchamp CG, Kellam JK, McMurtry RY. The results of plating humeral shaft fractures in patients with multiple injuries. The Sunnybrook experience. J Bone Joint Surg Br 1985;67:293-296.

5. Robinson CM, Bell KM, Court-Brown CM, McQueen MM. Locked nailing of humeral shaft fractures. Experience in Edinburgh over a two-year period. $\mathrm{J}$ Bone Joint Surg Br 1992;74:558-562.

6. Flinkkila T, Ristiniemi J, Hamalainen M. Nonunion after intramedullary nailing of humeral shaft fractures. J Trauma 2001;50:540-544.

7. Lin J, Chiang H, Hou SM. Open exchange locked nailing in humeral nonunions after intramedullary nailing. Clin Orthop Rel Res 2003;411:260-268.

8. Kontakis GM, Papadokostakis GM, Alpantaki K, Chlouverakis G, Hadjipavlou AG, Giannoudis PV. Intramedullary nailing for non-union of the humeral diaphysis: a review. Injury 2006;37:953-960.

9. Muller M, Nazarian S, Koch P, Schatzker J. The comprehensive classification of fractures of the long bones. Berlin: Springer; 1990.

10. Gustilo RB, Anderson JT. Prevention of infection in the treatment of one thousand and twenty-five open fractures of long bones: retrospective and prospective analyses. J Bone Joint Surg Am 1976;58:453-458.

11. Stewart MJ, Hundley JM. Fractures of the humerus; a comparative study in methods of treatment. J Bone Joint Surg Am 1955;37:681-692.

12. Sarmiento A, Zagorski JB, Zych GA, Latta LL, Capps CA. Functional bracing for the treatment of fractures of the humeral diaphysis. J Bone Joint Surg Am 2000;82:478-486.
13. Mahabier KC, Vogels LM, Punt BJ, Roukema GR, Patka P, Van Lieshout EM. Humeral shaft fractures: retrospective results of non-operative and operative treatment of 186 patients. Injury 2013;44:427-430.

14. Ekholm R, Ponzer S, Tornkvist H, Adami J, Tidermark J. Primary radial nerve palsy in patients with acute humeral shaft fractures. J Orthop Trauma 2008;22:408414.

15. Hughes RE, Schneeberger AG, An KN, Morrey BF, O'Driscoll SW. Reduction of triceps muscle force after shortening of the distal humerus: a computational model. J Shoulder Elbow Surg 1997;6:444-448.

16. Li XK, Wang HQ, Wei YY, Wu ZX. Treatment of nonunions of humeral fractures with interlocking intramedullary nailing. Chin J Traumatol 2008;11:335340.

17. Wu CC, Shih $\mathrm{CH}$. Treatment for nonunion of the shaft of the humerus: comparison of plates and Seidel interlocking nails. Can J Surg 1992;35:661-665.

18. Lammens J, Bauduin G, Driesen R, et al. Treatment of nonunion of the humerus using the Ilizarov external fixator. Clin Orthop Rel Res 1998;353:223-230.

19. Chapman JR, Henley MB, Agel J, Benca PJ. Randomized prospective study of humeral shaft fracture fixation: intramedullary nails versus plates. J Orthop Trauma 2000;14:162-166.

20. McCormack RG, Brien D, Buckley RE, McKee MD, Powell J, Schemitsch EH. Fixation of fractures of the shaft of the humerus by dynamic compression plate or intramedullary nail. A prospective, randomised trial. J Bone Joint Surg Br 2000;82:336-339.

21. Paris $H$, Tropiano $P$, Clouet D'orval $B$, Chaudet $H$, Poitout DG. [Fractures of the shaft of the humerus: systematic plate fixation. Anatomic and functional results in 156 cases and a review of the literature]. Rev Chir Orthop Reparatrice Appar Mot 2000;86:346-359.

22. Hems TE, Bhullar TP. Interlocking nailing of humeral shaft fractures: the Oxford experience 1991 to 1994. Injury 1996;27:485-489.

23. Ilyas I, Younge DA. Locked intramedullary nailing for difficult nonunions of the humeral diaphysis. Int Orthop 2003;27:278-281.

24. Kesemenli CC, Subasi M, Arslan H, Necmioglu S, Kapukaya A. Treatment of humeral diaphyseal nonunions by interlocked nailing and autologous bone grafting. Acta Orthop Belg 2002;68:471-475.

25. McKee MD, Miranda MA, Riemer BL, et al. Management of humeral nonunion after the failure of locking intramedullary nails. J Orthop Trauma 1996;10:492-499. 